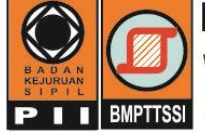

\title{
The Mechanics Properties of Self-Compacting Concrete Using Red-Tile Waste as Substitution of Fine Aggregates
}

\author{
Crezensia Alfiora Deadema Dias Octobenita ${ }^{1}{ }^{*}$ Ade Lisantono ${ }^{2}$ \\ ${ }^{1}$ International Civil Engineering Program (ICEP), Department of Civil Engineering \\ ${ }^{2}$ Faculty of Engineering, Universitas Atma Jaya Yogyakarta \\ adelisantono@mail.uajy.ac.id
}

Received: 15 September 2017 Revised: 15 November 2017 Accepted: 23 November 2017

\begin{abstract}
This paper presents the mechanics properties of Self-Compacting Concrete (SCC) using red-tile waste as substitution of fine aggregates. The proportions of red-tile waste substitution were 10\%; 20\%; 30\%; 40\%; and $50 \%$ of fine aggregates by weight. Viscocrete-10 was used to maintain the workability and flowability of SCC. 72 cylinder specimens with the size of $(150 \times 300) \mathrm{mm}$ and 18 beam specimens with the size of $(100 \times 100 \times 500) \mathrm{mm}$ were cast and tested in this study. The mechanics properties of SCC that were studied in this study were compressive strength; modulus of elasticity; and modulus of rupture. The compressive strength of SCC was tested at 7; 14; and 28 days. While the modulus of elasticity and modulus of ruptures were tested only at 28 days. The result shows that the maximum compressive strength; modulus of elasticity, and modulus of rupture were obtained from SCC using red-tile waste with the proportion of $50 \%$. The compressive strength of SCC using red-tile with the proportion of 50\% at 7; 14; and 28 days were 64.746 MPa; $65.564 \mathrm{MPa}$; and $71.940 \mathrm{MPa}$, respectively. While modulus of elasticity and modulus of rupture at 28 days were $25863.192 \mathrm{MPa}$ and $7.076 \mathrm{MPa}$, respectively.
\end{abstract}

Keywords: Self-compacting concrete, red tile waste, viscocrete-10, compressive strength, modulus of elasticity, modulus of rupture

\begin{abstract}
Abstrak
Makalah ini menyajikan sifat-sifat mekanik dari beton memadat sendiri yang menggunakan limbah genteng merah sebagai substitusi agregat halus. Proporsi substitusi limbah genteng merah adalah 10\%; 20\%; 30\%; 40\%; dan 50\% terhadap berat. Digunakan viscocrete-10 untuk menjaga sifat mudah dikerjakan dan mudah mengalir pada beton memadat sendiri. 72 benda uji silinder dengan ukuran $(150 \times 300) \mathrm{mm}$ dan 18 benda uji balok dengan ukuran $(100 \times 100 \times 500)$ telah dibuat dan diuji dalam studi ini. Sifat-sifat mekanik yang dipelajari adalah kuat tekan, modulus elastisitas dan modulus rupture. Kuat tekan dari beton memadat sendiri diuji pada umur beton 7; 14; dan 28 hari. Sedangkan modulus elastisitas dan modulus ruptures diuji hanya pada umur 28 hari. Hasil studi menunjukkan bahwa kuat tekan, modulus elastisitas, dan modulus ruptures maksimum diperoleh pada substitusi limbah genteng merah dengan proporsi 50\%. Kuat tekan beton memadat sendiri dengan proporsi substitusi $50 \%$ pada umur beton 7, 14, dan 28 hari berturut-turut adalah 64,564 MPa; 65,564 MPa; dan 71,940 MPa. Sedangkan modulus elastisitas dan modulus ruptures dari beton memadat sendiri dengan proporsi substitusi 50\% pada umur beton 28 hari berturut-turut adalah 25863,192 MPa dan 7,076 MPa.
\end{abstract}

Kata-kata kunci: Beton memadat sendiri, limbah genteng merah, viscocrete-10, kuat tekan, modulus elastisitas, modulus rupture 


\section{Introduction}

Concrete is a construction material for building, real estate, bridge, road, dam and etc. The increasing of the human population made the industrial construction was also increasing. Therefore, the concrete demand was also increasing. Concrete composes from various kinds of material such as fine aggregate, coarse aggregate, cement and water. However, due to the high demand of concrete, it causes the material mining on a large scale, like sand mining and gravel mining. That activities can destroy the nature. Therefore, it needs a solution that can reduce the mining natural materials of sand and gravel. One of the ways to solve that problem is utilization of recycle aggregate from construction waste.

One of waste material that can be used to substitute sand and gravel in concrete is red tile waste. Usually, red tile waste just discarded and became waste materials. In fact, red tile waste can be recycle and utilized became material that useful and has economic value. Red tile waste can be used to be substitution material of fine aggregate and coarse aggregate in conrete. The production cost to make concrete will be cheaper if red tile waste is using as the aggregate. Furthermore, concrete with red tile waste aggregate has low thermal conductivity. At the same time, concrete with red tile waste aggregate also has several disadvantages such as the compressive strength is not so high as normal concrete that is using natural aggregates and has high rate water absorption. The hardeners of red tile waste aggregate depend on the quality of the combustion.

One of the concrete type that is usually used in the construction is 'Self Compacting Concrete' (SCC). The application of SCC is considered more practical and faster than normal concrete, because it does not need vibrator and it can flow by itself. The red tiles waste has high rate of water absorption, it results that the concrete has a quick hardening in just a few minutes after mixing. So, to make the SCC using red tile waste as aggregate must be under Saturated Surface Dry (SSD) condition.

Investigation of SCC has been conducted by several researchers (Dehn et al., 2000; Sugiharto and Kusuma, 2001; Sonebi, M., 2004; Brouwers and Radix, 2005; Domone, 2007; Hubertova and Hela, 2007; Rusyandi et al., 2012). However, these investigations did not address the red tile waste utility into the SCC.
Investigation of SCC using red tile waste had been done by Herbudiman and Dewi (2012). In this research, the red tile waste used as a powder with the proportion of $10 ; 20$; and $30 \%$ by weight, and the red tile waste as substitution of coarse aggregate with the proportion of $45 ; 50$; and $55 \%$ by weight. The physical properties of red tile waste in that study were: SSD density $2.11 \mathrm{~kg} / \mathrm{cm}^{3}$; absorption $28.9 \%$, amount of mud $14.89 \%$, and water content 11.5 . The study reported that the compressive strength of the SCC at age 28 days was $30.58 \mathrm{MPa}$.

Poerwadi et al. (2014) also conducted an experimental program using of the zeolite local mineral on SCC. The result of this study was reported that compressive strength with variation of zeolite $0,5,10$ and $15 \%$ were $25.23 \mathrm{MPa}, 25.74$ $\mathrm{MPa}, 28.06 \mathrm{MPa}, 26.76 \mathrm{MPa}$, respectively.

So, study on SCC with red tile waste as substitution of fine aggregates is still needed. The aim of this research is to study the effect of red tile waste as substitution of fine aggregate on mechanical properties of SCC with proportion of substitution are $10 \% ; 20 \% ; 30 \%$; $40 \%$; and $50 \%$.

\section{Basic theory}

\section{Concrete}

The good fresh concrete is concrete that can be stirred, transported, poured, and solidified. There is no tendency for separation of gravel from the mixing and the separation of water and cement mixture. While the good hard concrete are strong, durable, waterproof, resistant, and little change in volume (Tjokrodimulyo, 2007). Concrete has advantages and disadvantages. The advantages of concrete are: (1) concrete is able to resist the compressive strength, as well as having characteristic that resistant to corrosion and decay by environmental conditions, (2) fresh concrete can easily be formed. the mold or form work can also be used repeatedly, so it is more economical, (3) fresh concrete can be sprayed on the surface of the cracked old concrete that cracked and can be fed into the concrete cracks in the repair process, (4) fresh concrete can be pumped, making it possible to construct in difficult position, and (5) concrete is wear-resistant and fire-resistant, so the treatment is cheaper.

On the other hand, concrete also has disadvantages, such as (1) concrete is considered unable to resist tensile force, so it is easy to crack. therefore, it needs a reinforcement to resist the tensile force, (2) hard concrete shrinks and expands when the temperature changes, so 
expansion joint needs to be made to prevent the occurrence of cracks due to temperature changes, (3) to get a perfectly watertight concrete, the making process must be done carefully, (4) Concrete that brittle (not ductile) should be examined carefully so after composited with the reinforcing steel it becomes ductile, especially on earthquake-resistant structures.

Portland cement

Portland cement is hydrolase cement produced by grinding the Portland cement slag that consist of silicate calcium that has hydrolase characteristic, and grinding with one or more additional materials that have sulfate calcium crystal form and can be added with other material (SNI- 15-2049-2004). Cement has several types based on its functions. The type of cement base on its function: (1) type I is Portland cement for general use and does not require any special requirements as required in other types, (2) type II is Portland cement requiring the resistance towards sulfate or medium hydration heat, (3) type III is Portland cement requiring the high resistance in the beginning state after the bond happens (4) type IV is Portland cement requiring the low hydration heat, (5) type $\mathrm{V}$ is Portland cement requiring the high resistance toward sulfate (SNI-15-2049-2004).

\section{Water}

Water as the mixture to make concrete must fulfil the minimum requirement, but it does not mean that water as mixture must qualify as drinking water. According to Tjokodimuljo (2007), the use of water as concrete mixture must fulfil the requirements as follows: (1) water must be clean, (2) water does not contain mud, oil, other flying things and not exceed 2 gram/liter, (3) water does not contain sodium that can be dissolved and can destroy the concrete, acid, organic substance more than 15 gram/liter, (4) water does not contain chloride or $\mathrm{Cl}>0.5$ gram/liter, (5) water does not contain sulfate substance $>1$ gram/liter

\section{Coarse aggregate.}

Coarse aggregate or called gravel is the result of natural des-integrase from rocks or in the form of crushed stone obtained from the quarry with a grain size more than $5 \mathrm{~mm}$. Gravel, in its use, must meet the following conditions: (1) grains of hard non-porous and its eternal meaning not broken due to weather influences, such as sun and rain, (2) Mud should be less than 1\%; when exceeding, it must be washed before usin, (3) it must not contain substances that could damage the rock; one example is reactive substance, such as alkali, (4) Coarse aggregate with grained flat can only be used if the amount does not exceed $20 \%$ of the overall weight.

Fine aggregate

According to Neville (2003), fine aggregate is the aggregate with size not more than $5 \mathrm{~mm}$. So, sand is include in fine aggregate. It can be either natural sand or sand from the quarry produced by rock breaker. The terms of fine aggregates in general according to SNI 03-6821-2002 are as follows: (1) Fine aggregate composed of grains of sharp and hard, (2) Fine grains are eternal, not broken or destroyed by the effects of the weather. The eternal nature of fine aggregate can be tested with a saturated solution of salt. If used sodium sulfate maximum destroyed part is $10 \%$ by its weight. (3) Fine aggregate should not contain more than 5\% mud (on dry weight); if the levels of mud exceed $5 \%$, the sand must be washed.

\section{Self-compacting concrete}

SCC is a concrete able to flow by itself and can be print on the formwork with or without vibrator. This concrete mixed leverage the aggregate size, aggregate portion and van admixture superplasticizer to achieve the specific viscosity that allows it to flow on their own without the vibrator. Once poured into a mold, the concrete can flow by itself and fill all space following the principle of gravity, including the casting of concrete with very narrow reinforcement steel. This concrete will flow into all the gaps in the casting place by utilizing its own weight of concrete mix.

Mix design for SCC must able fulfil the filling ability, passing ability and segregation resistance. Filling ability is the ability of SCC to flow and fill overall the mold part by its own weight. Passing ability is the ability of SCC to flow and pass the gap between the steel reinforcement or the narrow gap without segregation or blocking. Segregation resistance is the ability of the concrete to keep the composition still homogeny, during transportation until casting the concrete. According to The European Guidelines for SCC (EFNARC, 2005), SCC testing requirement using several measuring devices are as follows (see Table 1).

\section{Red tile waste}

Tile is an element of a building that was used as a roof. It is made of clay or without a mixture of other materials, and burned at high temperatures, so it cannot be destroyed when immersed in the water. The clay has the mineral silica and alumina so that when the clay is combusted at a particular 
temperature it will harden. The red tile waste can be used as fine aggregate to make concrete. However, before using it as concrete mixture, the tile fragment must be pounded first to get the fine aggregate size, less than $5 \mathrm{~mm}$, and still retained in sieve number 200 .

Table 1. Self compacting concrete requirement

\begin{tabular}{ccccc}
\hline \multirow{2}{*}{ Test } & \multirow{2}{*}{ Method } & \multirow{2}{*}{ Unit } & \multicolumn{2}{c}{ Limitations } \\
\cline { 4 - 5 } Filling ability & Slump flow & $\mathrm{mm}$ & Minimum & Maximum \\
& V-funnel & second & 6.0 & 850 \\
\hline Passing ability & L-shaped box & $\mathrm{h} 2 / \mathrm{h} 1$ & 0.8 & 12 \\
& J-ring & $\mathrm{mm}$ & 0.0 & 1 \\
\hline Viscosity & $\mathrm{T}_{500}$ slump flow & second & 2.0 & 10 \\
& V-funnel & second & 0.0 & 25 \\
\hline
\end{tabular}

Red tile waste

Tile is an element of a building that was used as a roof. It is made of clay or without a mixture of other materials, and burned at high temperatures, so it cannot be destroyed when immersed in the water. The clay has the mineral silica and alumina so that when the clay is combusted at a particular temperature it will harden. The red tile waste can be used as fine aggregate to make concrete. However, before using it as concrete mixture, the tile fragment must be pounded first to get the fine aggregate size, less than $5 \mathrm{~mm}$, and still retained in sieve number 200 .

\section{Viscocrete-10}

Viscocrete-10 is superplasticizer having brownish white color and it can work in many different mechanisms. This superplasticizer is suitable for concrete mix that needs long transportation and has high workability. The advantage of Viscocrete-10 can reduce the water consumption until $30 \%$ (Sika Indonesia, 2007). The advantages of Viscocrete-10 are: The reduction of water in large amount will produce concrete with high density, high strength concrete and reduce permeability. The effect of good water reduction will produce the good workability, easy to cast and curing. That is why it is suitable to use in SCC. It reduces the shrinkage and crack. It reduces carbonation. It increases the water proofing.

\section{Slump flow}

Slump flow value is used to measure the level of workability of mix concrete. The greater slump flow value, the more watery and easier concrete to work with. Conversely, the smaller the value of slump flow, the more viscous and more difficult concrete to make. Slump flow value varies between 600-725 mm (Lisantono and Hehanussa, 2009).

L-shaped Test
In this research to test the slump value, the author used L-shape flow test. According to State of the Art report of RILEM technical Committee 174SCC (Skarendahl, 2000), the result of L-shaped flow test is well corresponded to the result of the slump flow test, i.e. reflecting the deformation capacity. The descent of the sample head has similar physical meaning with the slump value (descent of the sample head in the slump flow test or the slump test). In other words, the slump flow test evaluates the 2-dimentional flow-ability of sample concrete under free condition and this type of L-shaped flow test evaluate the one-dimensional flow-ability under directionally restrained condition.

\section{Compressive strength}

The compressive strength of concrete is the ability to receive a compressive force per unit area. The strength of concrete identifies the quality of a structure. The compressive strength of concrete can be obtained from the standardized cylinder specimen. The dimension of the cylinder specimen is $(150 \mathrm{~mm} \times 300 \mathrm{~mm})$. The formula to get the concrete compressive strength based on laboratory experiment are as follows (Antono, 1995):

$$
f c^{\prime}=\frac{P}{A}
$$

Where, fc' is compressive strength (MPa), $\mathrm{P}$ is $\operatorname{load}(\mathrm{N})$ and $\mathrm{A}$ is area of the specimen.

Modulus of elasticity

Different from steel material, the modulus of elasticity of concrete varies according to its strength. Modulus of elasticity also depends on the age of the concrete, the properties of aggregates and cement, loading speed, type and size of specimen. Usually modulus compressive at $25 \%$ to $50 \%$ of the compressive strength ( $\mathrm{fc}^{\prime}$ ) is taken as the modulus of elasticity (Wang et al., 1986). The 
formula to determine modulus of elasticity of normal concrete can be used:

$$
E c=4700 x \sqrt{f c^{\prime}}
$$

Where, $\mathrm{Ec}=$ modulus of elasticity $(\mathrm{MPa}), \mathrm{fc}^{\prime}=$ concrete compressive strength $(\mathrm{MPa})$.

\section{Modulus of rupture}

Beam flexural strength is the flexural stress resulting from the bending moment divided by the elastic modulus of section. Beam flexural strength is an important factor in determining the mechanical properties and characteristics of the concrete itself. The components affecting the strength of concrete are water cement ratio, the degree of density, concrete age, type of cement, the amount of cement and aggregate quality.

Distance from the sides of the beam until the end of the beam is very important to determine the formula used. One of method that used to test the flexural strength of the beam is a beam bending test with one loading point. The beam specimen for modulus of rupture testing can be seen in Figure 1 and the flexural strength of the beam was calculated by the following equation:

$$
\sigma=\frac{3 P L}{2 b h^{2}}
$$

Where, $\sigma$ is flexural strength $(\mathrm{MPa}), \quad \mathrm{P}$ is maximum load that resulted in the collapse of the beam specimen $(\mathrm{N}), \mathrm{L}$ is span length between the two beams pedestal $(\mathrm{mm}), \mathrm{b}$ is average width of the beam cross-section collapses $(\mathrm{mm})$, and $\mathrm{h}$ is average high beams at the cross collapse $(\mathrm{mm})$
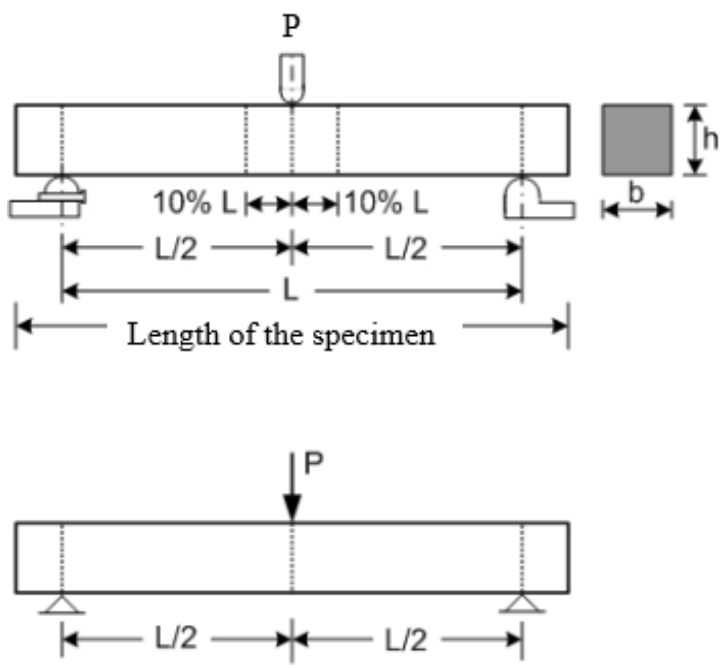

Figure 1. Modulus of rupture testing

\section{Methodology of Research}

This experimental program was conducted in the Laboratory of Structural and Building Materials and Laboratory of Transportation, Faculty of Engineering, Department of Civil Engineering, Universitas Atma Jaya Yogyakarta. The study was conducted to determine the concrete compressive strength, modulus of elasticity and modulus of rupture of SCC using red tile waste as substitution of fine aggregate. The proportion of red tile waste are $0,10,20,30,40$ and $50 \%$. The used plasticizer was Viscocrete-10 with proportion of $1.25 \%$ of weight of portland-cement. The compressive strength testing was conduct when the concrete at the age of 7, 14 and 28 days. While the modulus of elasticity and modulus of rupture testing were conducted when the concrete only at the age of 28 days.

The material of coarse aggregate was taken from Clereng, Kulon Progo Yogyakarta. While sand or fine aggregate was taken from Progo River. The water was taken from Laboratory of Structure and Building Materials, Faculty of Engineering, Department of Civil Engineering, Universitas Atma Jaya Yogyakarta. The portland-cement used type I. The admixture of Viscocrete-10 was used to maintain the workability and the flow ability of SCC. While the red tile used for substitution of fine aggregate was red tile waste.

The equipment that used in this research are, cylinder mold with diameter $150 \mathrm{~mm}$ and height $300 \mathrm{~mm}$, beam mold with size (100x100x500) $\mathrm{mm}$, abrams cone with upper diameter $100 \mathrm{~mm}$, bottom diameter $200 \mathrm{~mm}$ and height $300 \mathrm{~mm}$, concrete mixer, scale, sieve, sieve machine, caliper, compression testing machine with brand ELE, universal testing machine with brand shimadzu UMH-30, compressometer with a precision $0.01 \mathrm{~mm}$, Los Angeles Abrasion machine, steel balls, oven, wire bucket, gardner standard color, $250 \mathrm{ml}$ and $500 \mathrm{ml}$ measuring glass.

Material testing was conducted to determine whether the materials used meet the requirements. Materials tested were fine and coarse aggregates. For coarse aggregate (split), the conducted test was the amount of mud test, wear test with Los Angeles Abrasion Machine, gradation test, density and absorption test, water content and soundness test. For fine aggregate (sand), the test conducted was organic substance test, amount of mud test, gradation test, density and absorption test and water content test. Total specimen that made in this experiment is shown in Table 2. 
Table 2. Specimens and variation

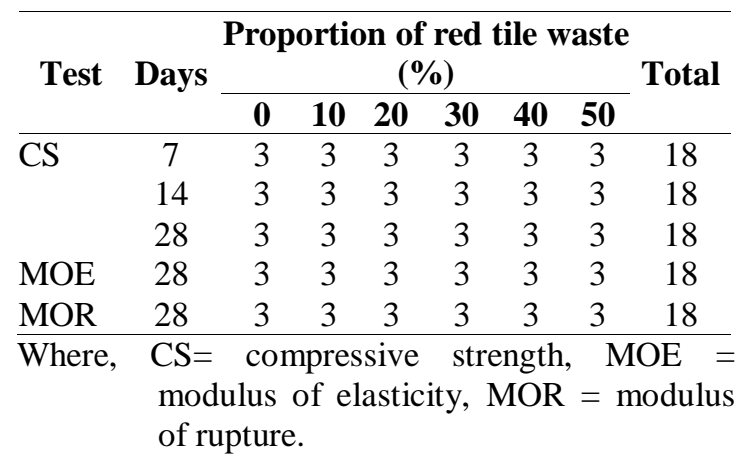

\section{Results and Discussion}

\section{Slump, slump flow and l-shaped testing}

The result of slump, slump flow and L-shaped test were shown in Table 3.

\section{Compressive strength testing}

Compressive strength test of the concrete conducted when concrete at the age 7,14 and 28 days using ELE machine. The result of compressive strength testing can be seen in Table 4 and Figure 2 for compressive strength graph. It can be seen from Table 4 and Figure 2 that the maximum compressive strength at the age 7,14 and 28 days obtained on concrete with $50 \%$ red tile waste proportion are $64.74 \mathrm{MPa}, 68.83 \mathrm{MPa}$ and 71.94 MPa, respectively.

Table 3. Result of slump, slump flow and Ishaped test

\begin{tabular}{cccc}
\hline $\begin{array}{c}\text { Red tile } \\
\text { waste } \\
\text { proportion }\end{array}$ & $\begin{array}{c}\text { Normal } \\
\text { slump } \\
(\mathbf{m m})\end{array}$ & $\begin{array}{c}\text { Slump } \\
\text { flow } \\
(\mathbf{m m})\end{array}$ & $\begin{array}{c}\text { L-shaped } \\
\text { box }\end{array}$ \\
\hline $0 \%$ & 128 & - & - \\
$10 \%$ & - & 720 & 0.86 \\
$20 \%$ & - & 590 & 0.846 \\
$30 \%$ & - & 560 & 0.88 \\
$40 \%$ & - & 650 & 0.923 \\
$50 \%$ & - & 590 & 0.892 \\
\hline
\end{tabular}

\section{Modulus of elasticity testing}

The modulus of elasticity is one of the properties of concrete related to ease of concrete deforms when receiving a given load. The larger the modulus values obtained, the smaller the strain that occurs. The result of modulus elasticity testing is shown in Table 5 and Figure 3. It can be seen from Table 5 and Figure 3 that the maximum modulus elasticity at the age 28 days obtained on concrete with red tile waste proportion of $50 \%$, and the value is $25863.19 \mathrm{MPa}$.

\section{Modulus of rupture testing}

Modulus of rupture of flexural strength conducted when the beam concrete at the age 28 days using Universal testing Machine (UTM). The result of modulus of rupture testing was shown in Table 6 and Figure 4. It can be seen from Table 6 and Figure 4 that the maximum modulus of rupture at the age 28 days obtained on concrete with red tile waste proportion of $50 \%$, and the value is 7.07 MPa.

Table 4. Result of compressive strength

\begin{tabular}{|c|c|c|c|c|c|}
\hline \multirow{2}{*}{ Age } & \multirow{2}{*}{$\begin{array}{l}\text { Red tile waste } \\
\text { proportion }\end{array}$} & \multicolumn{3}{|c|}{ Compressive strength (MPa) } & \multirow{2}{*}{$\begin{array}{c}\text { The average compressive } \\
\text { strength (MPa) }\end{array}$} \\
\hline & & I & II & III & \\
\hline \multirow{6}{*}{7} & $0 \%$ & 33.8445 & 33.8445 & 40.7115 & 36.1335 \\
\hline & $10 \%$ & 43.6545 & 39.7305 & 40.2210 & 41.2020 \\
\hline & $20 \%$ & 51.0120 & 48.0690 & 46.1070 & 48.3960 \\
\hline & $30 \%$ & 53.4645 & 53.9550 & 55.4265 & 54.2820 \\
\hline & $40 \%$ & 62.2935 & 62.7840 & 63.7650 & 62.9475 \\
\hline & $50 \%$ & 65.7270 & 63.7650 & 64.7460 & 64.7460 \\
\hline \multirow{6}{*}{14} & $0 \%$ & 40.2210 & 38.7495 & 39.2400 & 39.4035 \\
\hline & $10 \%$ & 43.6545 & 44.6355 & 44.1450 & 44.1450 \\
\hline & $20 \%$ & 51.0120 & 52.9740 & 52.4835 & 52.1565 \\
\hline & $30 \%$ & 58.8600 & 58.3695 & 60.3315 & 59.1870 \\
\hline & $40 \%$ & 64.7460 & 65.7270 & 66.2175 & 65.5635 \\
\hline & $50 \%$ & 69.6510 & 69.1605 & 67.6890 & 68.8335 \\
\hline \multirow{6}{*}{28} & $0 \%$ & 42.1830 & 44.6355 & 40.7115 & 42.5100 \\
\hline & $10 \%$ & 41.6925 & 52.9740 & 44.1450 & 46.2705 \\
\hline & $20 \%$ & 55.9170 & 53.9550 & 55.4265 & 55.0995 \\
\hline & $30 \%$ & 63.7650 & 65.2365 & 62.7840 & 63.9285 \\
\hline & $40 \%$ & 69.6510 & 69.1605 & 70.6320 & 69.8145 \\
\hline & $50 \%$ & 72.1035 & 72.5940 & 71.1225 & 71.9400 \\
\hline
\end{tabular}




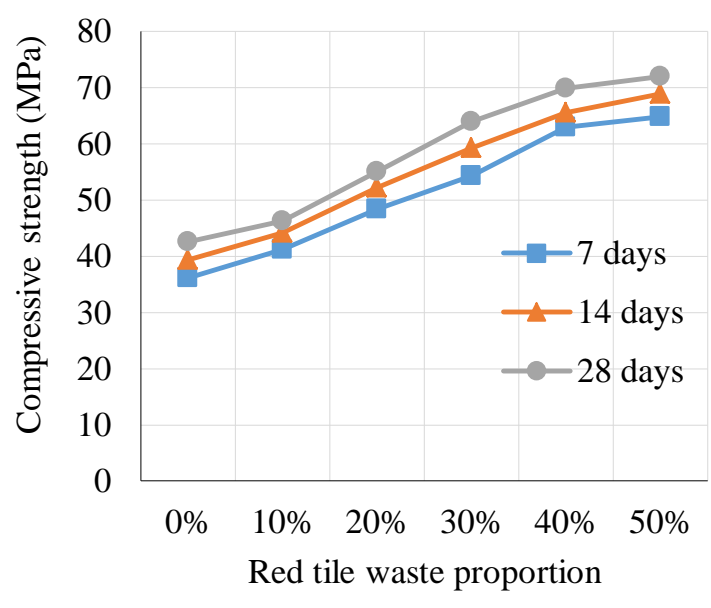

Figure 2. Compressive strength

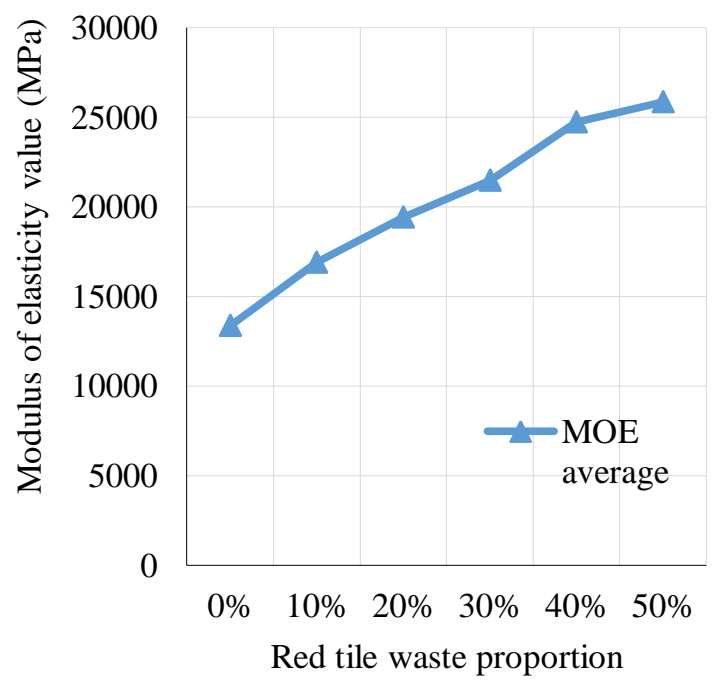

Figure 3. Modulus of elasticity

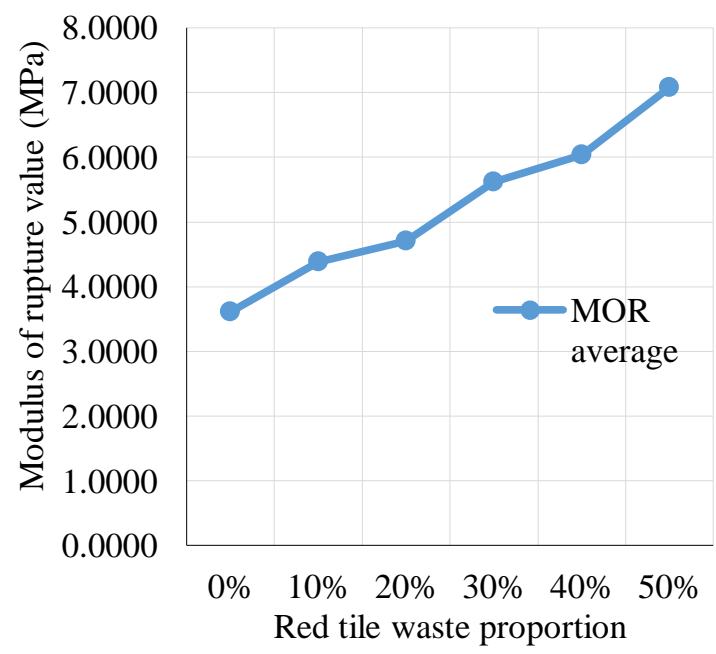

Figure 4. Modulus of rupture
Table 5. Result of modulus of elasticity

\begin{tabular}{cccc}
\hline $\begin{array}{c}\text { Proportion } \\
\text { of red tile } \\
\text { waste }\end{array}$ & $\begin{array}{c}\text { Cylinder } \\
\text { number }\end{array}$ & $\begin{array}{c}\text { Modulus of } \\
\text { elasticity }\end{array}$ & $\begin{array}{c}\text { Modulus } \\
\text { of elasticity } \\
\text { average }\end{array}$ \\
\hline \multirow{2}{*}{$0 \%$} & 1 & 13418.8383 & \\
& 2 & 13971.3318 & 13365.4053 \\
& 3 & 12706.0458 & \\
\hline \multirow{2}{*}{$10 \%$} & 1 & 16164.2992 & \\
& 2 & 17498.9979 & 16888.3566 \\
& 3 & 17001.7726 & \\
\hline \multirow{2}{*}{$20 \%$} & 1 & 19399.6212 & \\
& 2 & 19194.1475 & 19419.1673 \\
& 3 & 19663.7334 & \\
\hline \multirow{3}{*}{$30 \%$} & 1 & 21357.1790 & \\
& 2 & 21643.9972 & 21488.3324 \\
& 3 & 21463.8210 & \\
\hline \multirow{3}{*}{$50 \%$} & 1 & 24724.9445 & \\
& 2 & 24692.5048 & 24716.7489 \\
& 3 & 24732.7974 & \\
\hline & 1 & 25912.5564 & \\
& 3 & 26232.8364 & 25863.1920 \\
\hline
\end{tabular}

Table 6. Result of modulus of rupture

\begin{tabular}{cccc}
\hline $\begin{array}{c}\text { Proportion } \\
\text { of red tile } \\
\text { waste }\end{array}$ & $\begin{array}{c}\text { Beam } \\
\text { number }\end{array}$ & $\begin{array}{c}\text { Modulus } \\
\text { of rupture } \\
\text { (mpa) }\end{array}$ & $\begin{array}{c}\text { Modulus } \\
\text { of rupture } \\
\text { average }\end{array}$ \\
\hline \multirow{2}{*}{$0 \%$} & 1 & 3.5667 & \\
& 2 & 3.6047 & 3.6161 \\
& 3 & 3.6768 & \\
\hline \multirow{2}{*}{$10 \%$} & 1 & 4.3693 & \\
& 2 & 4.3454 & 4.3827 \\
& 3 & 4.4333 & \\
$2 \%$ & 1 & 4.6535 & \\
& 2 & 4.6980 & 4.7103 \\
& 3 & 4.7795 & \\
\hline \multirow{3}{*}{$30 \%$} & 1 & 5.7559 & \\
& 2 & 5.5936 & 5.6175 \\
& 3 & 5.5030 & \\
$40 \%$ & 1 & 5.9850 & \\
& 2 & 6.2697 & 6.0338 \\
& 3 & 5.8466 & \\
\hline \multirow{3}{*}{$50 \%$} & 1 & 6.7264 & \\
& 2 & 7.2698 & 7.0757 \\
& 3 & 7.2308 & \\
\hline
\end{tabular}

\section{Conclusion}

Based on the experimental results, the conclusions are : the average compressive strength of SCC for red tile waste with the proportion of $0,10,20,30$, 40 and $50 \%$ at the age 7 days are $36.13 \mathrm{MPa}, 41.20$ $\mathrm{MPa}, 48.39 \mathrm{MPa}, 54.28 \mathrm{MPa}, 62.94 \mathrm{MPa}$ and 64.74 MPa, respectively. The compressive strength at 14 days for the proportion of $0,10,20,30,40$ and $50 \%$ are $39.41 \mathrm{MPa}, 44.14 \mathrm{MPa}, 52.15 \mathrm{MPa}$, $59.18 \mathrm{MPa}, 65.5635 \mathrm{MPa}$ and $68.83 \mathrm{MPa}$, 
respectively. While the compressive strength at the age 28 days for the proportion of $0,10,20,30,40$ and $50 \%$ are $42.51 \mathrm{MPa}, 46.27 \mathrm{MPa}, 55.09 \mathrm{MPa}$, $63.92 \mathrm{MPa}, 69.81 \mathrm{MPa}$ and $71.94 \mathrm{MPa}$, respectively.

The maximum compressive strength of SCC at the age 7,14 and 28 days obtained on concrete with $50 \%$ red tile waste proportion, that are $64.74 \mathrm{MPa}$, $68.83 \mathrm{MPa}$ and $71.94 \mathrm{MPa}$, respectively. The average modulus of elasticity value of red tile waste with proportion $0,10,20,30,40$ and $50 \%$ when the concrete at the age 28 days are 13365.40 $\mathrm{MPa}, \quad 16888.35 \mathrm{MPa}, 19419.16 \mathrm{MPa}$, 21488.33MPa, 24716.74 MPa and 25863.19 MPa, respectively.

The maximum modulus elasticity value when the concrete at the age 28 days obtained on concrete with red tile waste proportion of $50 \%$, and the value is $25863.19 \mathrm{MPa}$. The average modulus of rupture value of red tile waste with proportion 0 , $10,20,30,40$ and $50 \%$ when the concrete at the age 28 days are $3.61 \mathrm{MPa}, 4.38 \mathrm{MPa}, 4.71 \mathrm{MPa}$, 5.61 MPa, 6.03 MPa and 7.07 $\mathrm{MPa}$, respectively. The maximum modulus of rupture of SCC at the age 28 days obtained on concrete with the red tile waste proportion of $50 \%$, and the value is 7.07 MPa.

\section{References}

Antono, A. (1995). Bahan Konstruksi Teknik Sipil, Penerbit Universitas Atma Jaya Yogakarta, Yogyakarta.

Brouwers, H. J. H., \& Radix, H. J. (2005). Selfcompacting concrete: theoretical and experimental study. Cement and Concrete Research,35(11), 2116-2136.

Dehn, F., Holschemacher, K. and Weiße, D.(2000). Self-Compacting Concrete (SCC) Time Development of the Material Properties and the Bond Behaviour, LACER No.5., Leipzig.

Domone, P. L. (2007). A Review of The Hardened Mechanical Properties of Self-Compacting Concrete. Cement and Concrete Composites, 29(1), 1-12.

EFNARC, BIBM, CEMBUREAU, EFCA, ERMCO. (2005). The European Guidelines for Self-Compacting Concrete.

Herbudiman, B. and Dewi, L.D. (2012). Beton Ringan Self-Compacting dengan Agregat dan Powder Limbah Pecahan Genting Merah, Prosiding Konferensi Nasional Teknik Sipil 6 (KoNTekS 6), Universitas Trisakti, Jakarta, 1-2 November, MB 33-41.
Hubertova, M. and Hela, R. (2007). Development and Experimental Study on the Properties of Lightweight Self Compacting Concrete, $5^{\text {th }}$ RILEM Symposium on Self Compacting Concrete, Ghent, Belgium, 2007.

Lisantono, A. and Hehanussa, G.P. (2009). Pengaruh Penggunaan Plastizicer pada Self Compacting Geopolymer Concrete dengan Atau tanpa Penambahan Kapur Padam, Jurnal Media Teknik Sipil, IX (2), 1-8.

Neville, A. M. (2003). Properties of Concrete 4th Edition, Pearson Education, Delhi.

Poerwadi, M.R., Zacoeb, A., Syamsudin R. (2014). Pengaruh Penggunaan Mineral Lokal Zeolit Alam terhadap Karakteristik Self Compacting Concrete (SCC), Department of Civil Engineering, Faculty of Engineering, Universitas Brawijaya, Malang.

PT. Sika Indonesia. (2007). Sika Viscocrete-10 High Performance Superplasticiser.

Rusyandi, K. , Mukodas, J., Gunawan, Y. (2012). Perancangan Beton Self Compacting Concrete (Beton Memadat Sendiri) dengan Penambahan Fly Ash dan Structuro, Jurnal Konstruksi Sekolah Tinggi Teknologi Garut, Vol. 10 No. 01.

Skarendahl, A. (2000). State of the Art report of RILEM Technical Committee 174-SCC, RILEM Publication, France.

SNI 03-6821. (2002). Spesifikasi Agregat Ringan untuk Batu Cetak Beton Pasangan Dinding, Badan Standardisasi Nasional BSN, Indonesia.

SNI 15-2049. (2004). Semen Portland, Badan Standardisasi Nasional BSN, Indonesia.

Sonebi, M. (2004). Medium Strength SelfCompacting Concrete Containing Fly Ash: Modelling Using Factorial Plans, Cement and Concrete Research, 34 (2004), 1199-1208.

Sugiharto, H. and Kusuma, G.H. (2001). Penggunaan Abu Terbang dan Viscocrete pada Self Compacting Concrete, Dimensi Teknik Sipil, Vol. 3, No. 1, Jurusan Teknik Sipil, Fakultas Teknik Sipil dan Perencanaan, Universitas Kristen Petra.

Tjokrodimuljo, K. (2007). Teknologi Beton, Teknik Sipil Universitas Gadjah Mada, Yogyakarta.

Wang C. K., Salmon, C. G., and Binsar, H. (1986). Disain Beton Bertulang, Edisi Keempat, Erlangga, Jakarta. 